\title{
Acute posterior multifocal placoid pigment epitheliopathy (APMPPE)
}

\author{
Ilaria Testi, Sandra Vermeirsch and Carlos Pavesio ${ }^{*}$
}

\begin{abstract}
Background: Acute posterior multifocal placoid pigment epitheliopathy (APMPPE) is a rare inflammatory eye disease, affecting the inner choroid and the outer retina. Recent advances in multimodal imaging have been important in the understanding of the pathophysiology of the disease, allowing a better characterization of the morphology of this condition.

Methods: Narrative review.

Results: In this review, a comprehensive overview of clinical features, imaging findings, treatment management, and long-term outcomes of patients with APMPPE will be provided.

Conclusions: Although APMPPE was originally believed to be a self-limited condition with a good prognosis, the disease can be recurrent and result in significant loss of vision function. Fundus imaging plays an important role in the diagnosis and management of the disease, allowing to evaluate response to treatment and onset of complications.
\end{abstract}

Keywords: Acute posterior multifocal placoid pigment epitheliopathy, APMPPE, Placoid epiteliopathy, Imaging, Optical coherence tomography angiography

\section{Introduction}

Acute posterior multifocal placoid pigment epitheliopathy (APMPPE) is a rare inflammatory disease, classified as part of the spectrum of the white dot syndromes, a terminology presently revised. Today it is classified within the group of choriocapillaritis diseases. The disorder was first described by Gass in 1968 as multiple, discrete, cream-coloured lesions located in the posterior pole of three young women complaining of painless visual reduction. At that time, the retinal pigment epithelium (RPE) was considered to be the primary site of inflammation [1]. However, as in the case of posterior uveitis, multimodal imaging played a key role in the characterisation of disease phenotype, and advances in imaging technologies have resulted in a better understanding of its pathophysiology. Multimodal imaging features in APMPPE support the most likely primary

\footnotetext{
* Correspondence: c.pavesio@nhs.net

Department of Uveitis, Moorfields Eye Hospital, National Health Service Foundation Trust, 162 City Rd, Old Street, London EC1V 2PD, UK
}

inflammatory involvement of the choriocapillaris with secondary photoreceptor disruption, resulting in the characteristic distinctive clinical phenotype of the disease.

This review article provides a comprehensive overview of the clinical features, imaging findings, treatment management, and long-term outcomes of the lesions that characterize patients with APMPPE.

\section{Epidemiology and demographics}

APMPPE is a rare disease, occurring predominantly in young healthy adults. The disorder is found equally between men and women, with a male to female ratio of 1.2:1 [2]. Data combined from published case reports identified 27 years as the mean age of onset of the disorder, with a range between the first and seventh decade, and over three quarters of cases occurring between 16 and 40 years of age $[2,3]$. The disease is more common in Caucasian people [2, 3].
Springer Open (c) The Author(s). 2021 Open Access This article is licensed under a Creative Commons Attribution 4.0 International License, which permits use, sharing, adaptation, distribution and reproduction in any medium or format, as long as you give appropriate credit to the original author(s) and the source, provide a link to the Creative Commons licence, and indicate if changes were made. The images or other third party material in this article are included in the article's Creative Commons licence, unless indicated otherwise in a credit line to the material. If material is not included in the article's Creative Commons licence and your intended use is not permitted by statutory regulation or exceeds the permitted use, you will need to obtain permission directly from the copyright holder. To view a copy of this licence, visit http://creativecommons.org/licenses/by/4.0/. 


\section{Etiopathogenesis}

The pathophysiology of the disease is supported by the characteristic findings on multimodal imaging, showing that APMPPE primarily affects the choriocapillaris and inner choroid, resulting in secondary changes to the outer retina and RPE [4-7]. However, the exact underlying etiologic mechanism is unknown, although an immune driven nature has been hypothesized based on the following associations. The disease is often preceded by a viral prodrome, therefore the hypothesis of its association with a presumed infective illness is suggestive [2, 8-12]. In addition, numerous cases of APMPPE have been reported in patients with a positive tuberculosis immunological test, suggesting an indirect mechanism eliciting an intraocular immune response [2, 3, 13]. The disease has also been linked with pre-existing autoimmune and autoinflammatory diseases, including psoriasis, sarcoidosis, erythema nodosum, eczema, and diabetes mellitus, and cases of patients developing such conditions after being diagnosed with APMPPE have also been described [14-16]. An increased incidence of both class I HLA antigen (HLA-B7) and class II HLA antigen (HLA-DR2) with a relative higher risk of 3.38 and 3.32 of developing ocular disease, respectively, has been reported in APMPPE patients [17]. The immune driven nature is also supported by the development of the disease after immunization with vaccines, including hepatitis $\mathrm{B}$, varicella, polio, and tetanus, suggesting a possible interplay between vaccines and specific $\mathrm{T}$-cell receptors of the host immune system [18-23].

\section{Clinical manifestations}

APMPPE clinically manifests with multifocal, yellowish creamy, subretinal, placoid lesions, located posteriorly to the equator, generally within the posterior pole (Fig. 1 A). Patients complain of bilateral sudden and painless visual loss, photopsias and paracentral scotomas. In most cases patients have bilateral disease with the second eye affected within a few days or weeks following the fellow eye. The lesions tend to gradually fade over few weeks, resulting in hyperpigmentation and chorioretinal atrophy (Fig. 1 B). New lesions may appear up to three weeks following the onset, coexisting with older lesions. The disease may be associated with minimal inflammatory reaction in the vitreous cavity, usually in the absence of anterior uveitis. Papillitis and retinal vasculitis may be present [2, 3, 24-26].

Although APMPPE is a primary ocular disease, neurological and systemic manifestations can also occur. Central nervous system complications include cerebral vasculitis, cavernous sinus thrombosis, meningoencephalitis, aseptic meningitis, stroke or transient ischaemic attack, seizures, sixth-cranial-nerve palsy, transient hearing loss and headaches [10, 27-30]. In addition, peripheral neuropathy has recently been described [27]. In a retrospective review of 56 cases diagnosed with APMPPE, Algahtani et al. reported cerebral vasculitis as the most common neurological complication, affecting $50 \%$ of the patients, following by isolate headaches in $26.8 \%$ [27].

\section{Ancillary imaging \\ Fundus photography}

Fundus photography is useful to document the appearance of APMPPE lesions and determine their morphological evolution and associated changes, including atrophy and hyperpigmentation (Fig. 1). In addition, onset of new lesions can be detected over the course of the disease. Thus, serial fundus photography from acute onset to the stage of healing is a useful tool that allows an objective assessment of disease activity, and can also help in detecting potential complications, including development of choroidal neovascularization clinically manifesting as haemorrhage contiguous to the scar [31-35].

\section{Fundus fluorescein angiography and Indocyanine green angiography}

Active APMPPE lesions show hypofluorescence in the early phases of fundus fluorescein angiography (FFA), but will become hyperfluorescent in the late frames. The early hypofluorescence is likely to represent poor perfusion or delayed filling of the choriocapillaris rather than choroidal signal attenuation from the overlying outer retina and/or RPE thickening/oedema, as initially believed by Gass [1, 5, 24-26]. The late hyperfluorescence is the result of the change in the polarity of the RPE, affected by ischaemia, resulting in a deficit of pumping that interferes with the movement of the fluid from the retina to the choroid. Another hypothesis has been put forward indicating that profound ischaemia of the outer retina could produce reactionary hyperpermeability and exudation from retinal vessels [36, 37]. Healed lesions may demonstrate hyper and hypofluorescence throughout the exam, reflecting RPE disturbance, namely window defect due to RPE atrophy and pigmentary changes.

On indocyanine green angiography (ICGA) active placoid lesions appear as hypofluorescent spots across all phases of the exam, likely due to poor perfusion of the choriocapillaris $[5,6,38,39]$. The ICGA signal usually normalizes as APMPPE lesions resolve. Although ICGA and FFA findings have been interpreted as suggesti of a choroidal origin to the disease, the alternative hypothesis suggesting a RPE origin with subsequent potential ICGA and early FFA signal attenuation by swollen/thickened RPE could potentially contribute to this presentation [39]. 

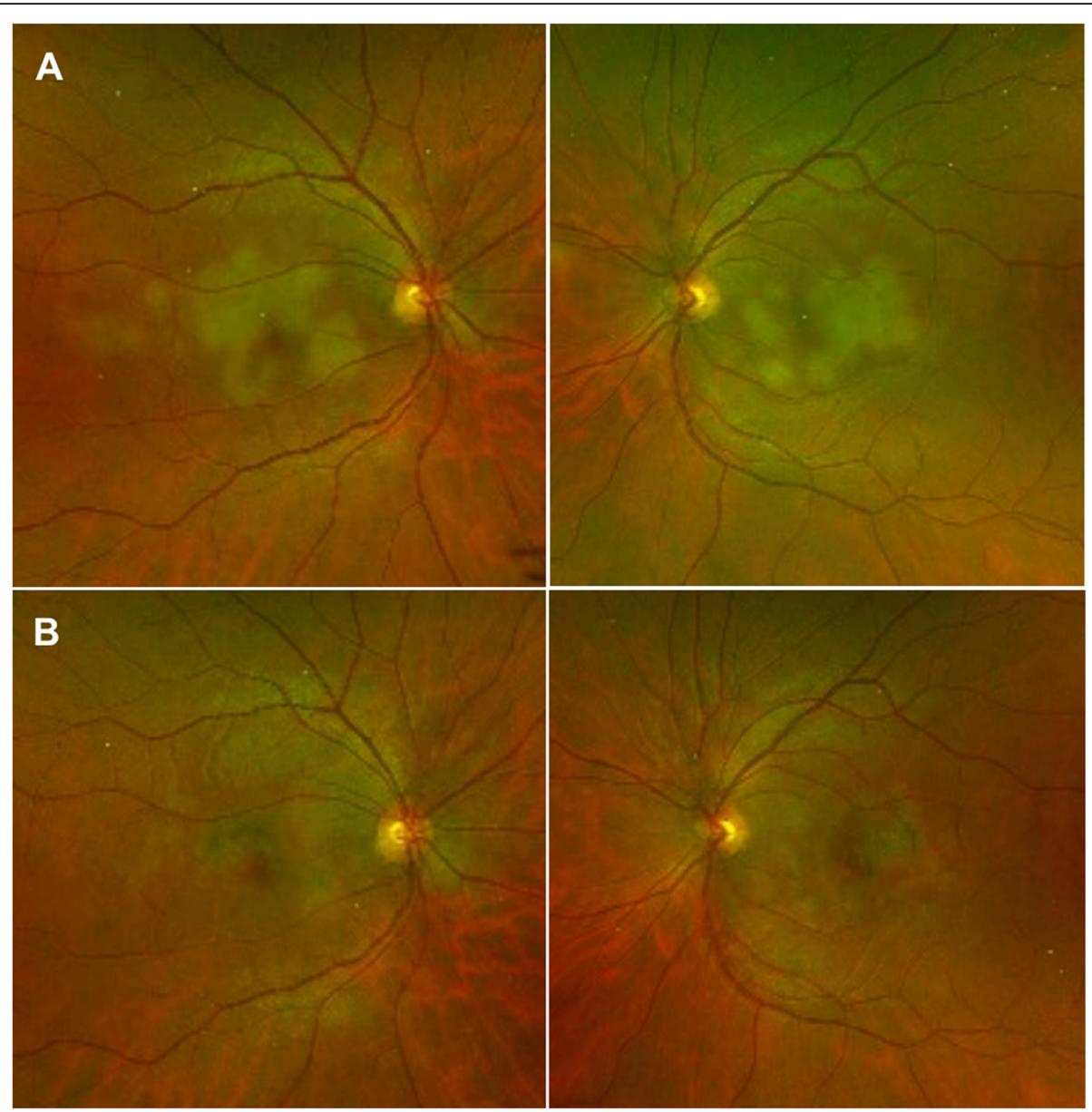

Fig. 1 Pseudocolour fundus photograph of acute posterior multifocal placoid pigment epitheliopathy (APMPPE). (A) Acute stage - Bilateral multifocal, yellowish creamy, placoid lesions, located at the posterior pole. (B) Inactive stage - Bilateral resolution of placoid lesions resulted in hyperpigmentation and chorioretinal atrophy

\section{Optical coherence tomography}

On spectral-domain optical coherence tomography (SDOCT), the placoid lesions in the acute stage appear as disruption of the outer retinal and ellipsoid zone, with the presence of hyperreflective material at the level of the outer retinal layers and RPE (Fig. 2 A) [24-26, 40]. Over the course of resolution of the placoid lesions, the hyperreflectivity of the outer retina disappears, resulting in either partial restoration of its appearance or focal areas of photoreceptors/RPE atrophy (Fig. 2 B) [41, 42].

Goldenberg described four distinct OCT phases of APMPPE, beginning with a dome-shaped elevation with disruption of the photoreceptor junction, that flattens soon after [43]. Two weeks later, the second stage is characterized by the detection of a distinct separation between the photoreceptor junction and the RPE. The third stage, occurring six weeks after disease onset, is characterized by increased RPE hyperreflectivity and union of the RPE and photoreceptor junction, followed by the resolution phase, starting at three months post disease onset, with the reformation of two distinct visible layers of photoreceptors and RPE. However, focal areas of photoreceptors/RPE atrophy can develop.

Accumulation of associated subretinal fluid might occur in APMPPE, and the presence of exudative retinal detachment mimicking acute Vogt-Koyanagi-Harada has been reported [44, 45]. Recently, Kohli et al. described three cases of APMPPE characterized in the acute phase by a SD-OCT revealing a splitting of the ellipsoid zone suggestive of bacillary layer detachment [46]. All cases showed complete resolution within one week. It has been hypothesized that the underlying impairment of choroidal vascularization could result into the photoreceptor (bacillary layer) stress and splitting. Since the photoreceptors get their nutrients from the choriocapillaris, the inner choroidal ischemia characterizing the acute stage of the disease could lead to the splitting of the bacillary layer. Once the inflammation resolves and 

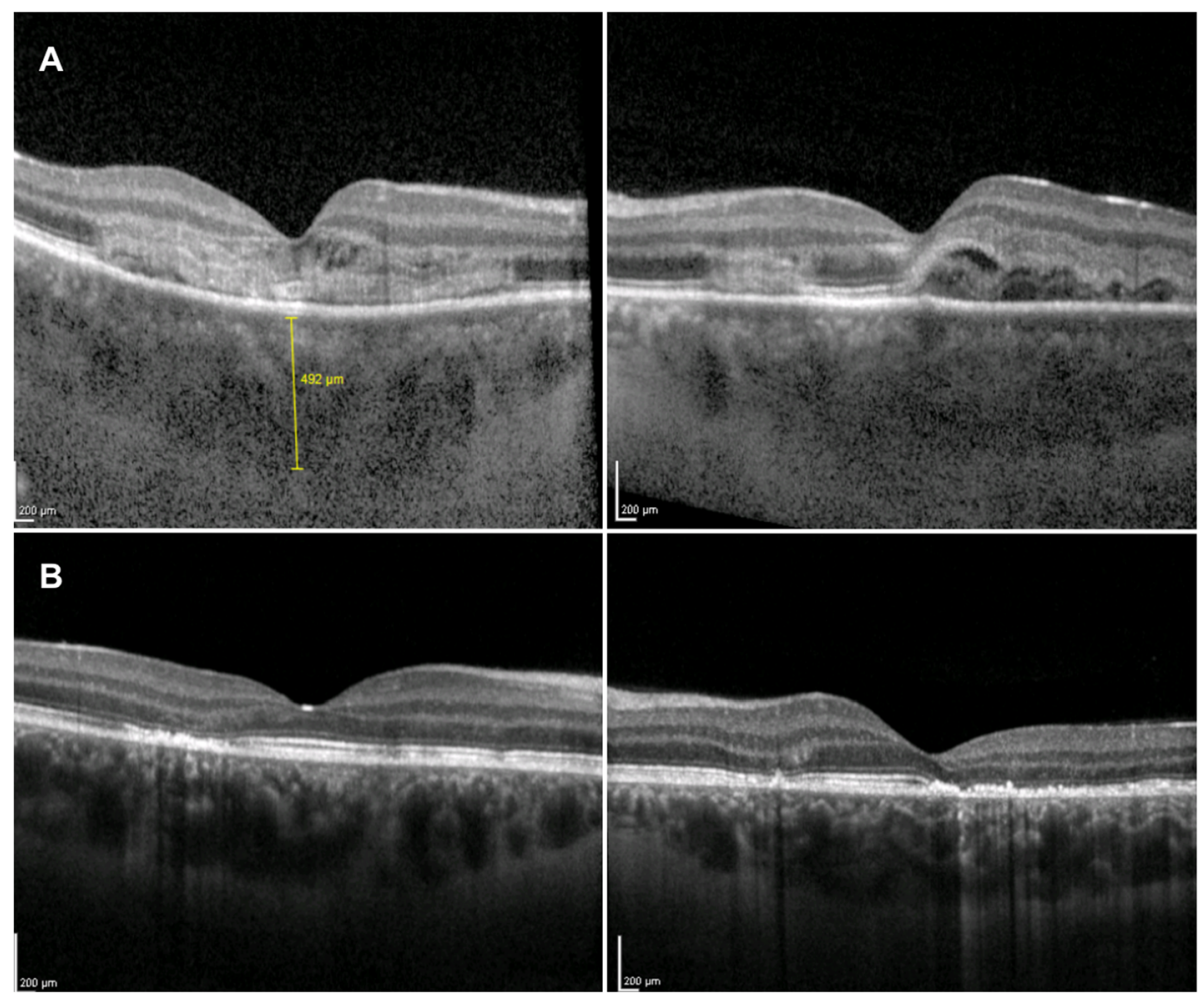

Fig. 2 Enhanced depth imaging optical coherence tomography (EDI-OCT) of acute posterior multifocal placoid pigment epitheliopathy (APMPPE). (A) Active stage - Bilateral disruption of the outer retinal and ellipsoid zone, with hyperreflectivity of outer retinal layers and retinal pigment epithelium (RPE), and bilateral increase in choroidal thickness. (B) Inactive stage - Resolution of the placoid lesions with disappearance of the hyperreflectivity of the outer retina, resulting in either partial restoration of its appearance or focal areas of photoreceptors/RPE atrophy; bilateral normalization of choroidal thickness

the choriocapillaris perfusion improves, the bacillary detachment then regresses [47-50]. Another possible explanation for the bacillary detachment could be the change in the polarity of the RPE, affected by ischaemia, resulting in a deficit of pumping that interferes with the movement of the fluid from the retina to the choroid.

During the acute phase of the disease enhanced depth imaging optical coherence tomography (EDI-OCT) shows choroidal thickening, improving with the resolution of the placoid lesions (Fig. 2) [44-46].

\section{Optical coherence tomography angiography}

Recent advances in the field of ocular imaging and development of optical coherence tomography angiography (OCT-A) have allowed a better assessment of APMPPE morphology. OCT-A visualizes retinal and choroidal circulations, and, providing segmented en-face images of blood flow in the retinal capillary plexuses and choriocapillaris, has allowed a better understanding of the pathophysiology of the choroidal vascular involvement characterizing the disease.

In patients with APMPPE, OCT-A demonstrates areas of decreased flow/flow void at the level of the choriocapillaris $[39,51-53]$. These areas of flow deficit correlate closely with the ischemic lesions manifesting as early hypofluorescent on FFA and hypofluorescent throughout the exam on ICGA [39, 51-53]. In addition, corresponding areas of outer retinal disruption on SDOCT co-localize with the areas of reduction of choriocapillaris flow on OCT-A. However, such areas of outer retinal changes on SD-OCT co-localize with greater areas of choriocapillaris flow deficit on OCT-A, supporting the hypothesis that APMPPE is primarily caused by an ischemic event occurring at the level of the inner choroid and secondary affecting the outer retina and RPE with photoreceptor disruption [39, 53]. OCT-A demonstrates a reversible inner choroidal hypoperfusion, showing normalisation of choroidal vasculature during follow-up.

\section{Fundus autofluorescence}

Fundus autofluorescence (FAF) acts a measure of RPE function, and autofluorescence characteristics have been recognized as a marker of disease activity, allowing prediction of therapy response and visual prognosis [54]. 

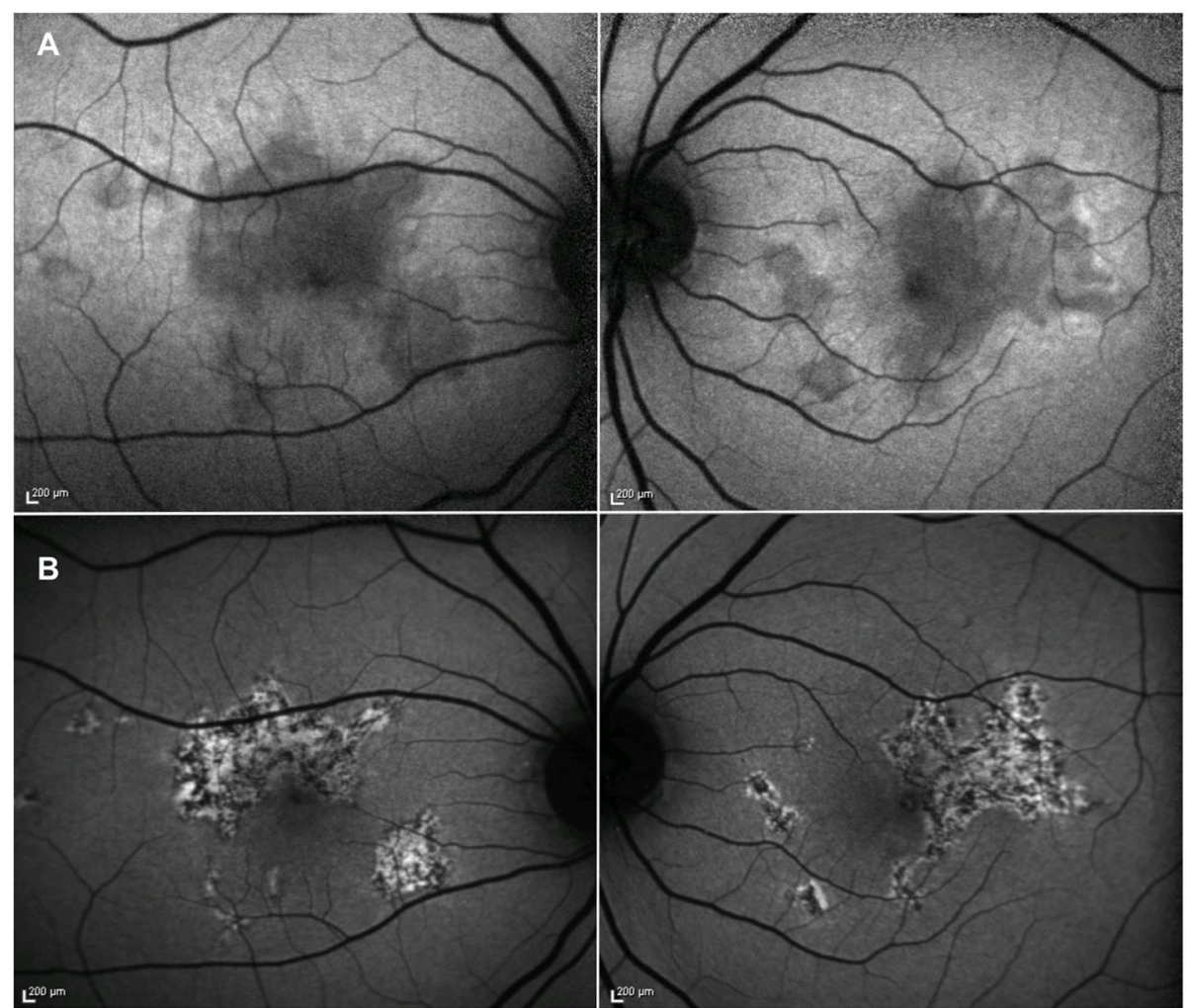

Fig. 3 Fundus autofluorescence of acute posterior multifocal placoid pigment epitheliopathy (APMPPE). (A) Active stage - Bilateral initial hypoautofluorescence corresponding to the hyper-reflectance of the outer retinal layers on optical coherence tomography (OCT). (B) Inactive stage - Progressive increase in hyperautofluorescence, resulting in a mixed pattern of hypoautofluorescence and hyperautofluorescence

APMPPE lesions show initial hypoautofluorescence corresponding to the hyper-reflectance of the outer retinal layers on SD-OCT, likely secondary to its masking effect (Fig. 3 A) [55]. A progressive increase in hyperautofluorescence is observed later on in the course of the disease when outer retinal findings progress to disruption of the RPE layer, with a mixed pattern of hypoautofluorescence and hyperautofluorescence (Fig. 3 B) [55,
56]. Later in the disease course, a more homogenous hypoautofluorescent pattern suggesting focal areas of photoreceptors/RPE atrophy might develop $[55,56]$.

Imaging features of APMPPE are described in Table 1.

\section{Laboratory and radiologic investigations}

Although the diagnosis of APMPPE is based on clinical features and multimodal imaging findings, an infectious

Table 1 Imaging features of acute posterior multifocal placoid pigment epitheliopathy (APMPPE)

\begin{tabular}{|c|c|c|c|c|c|c|c|}
\hline & & FFA & ICGA & FAF & SD-OCT & EDI-OCT & OCT-A \\
\hline \multirow[t]{2}{*}{ APMPPE } & $\begin{array}{l}\text { Active } \\
\text { disease }\end{array}$ & $\begin{array}{l}\text { Early hypofluorescence, } \\
\text { late hyperfluorescence }\end{array}$ & $\begin{array}{l}\text { Early and late } \\
\text { hypofluorescence }\end{array}$ & $\begin{array}{l}\text { Initial } \\
\text { hypoautofluorescence, } \\
\text { with progressive } \\
\text { increase in } \\
\text { hyperautofluorescence }\end{array}$ & $\begin{array}{l}\text { Disruption of the outer } \\
\text { retinal and ellipsoid } \\
\text { zone, with } \\
\text { hyperreflective material } \\
\text { at the level of the outer } \\
\text { retinal layers and RPE }\end{array}$ & $\begin{array}{l}\text { Choroidal } \\
\text { thickening }\end{array}$ & $\begin{array}{l}\text { Areas of flow } \\
\text { void at the } \\
\text { level of the } \\
\text { choriocapillaris }\end{array}$ \\
\hline & $\begin{array}{l}\text { Healed } \\
\text { disease }\end{array}$ & $\begin{array}{l}\text { Early and late hyper } \\
\text { and hypofluorescence } \\
\text { reflecting RPE } \\
\text { disturbance (window } \\
\text { defect and pigmentary } \\
\text { changes) }\end{array}$ & Normalisation & $\begin{array}{l}\text { Mixed pattern of } \\
\text { hypoautofluorescence } \\
\text { and } \\
\text { hyperautofluorescence, } \\
\text { followed by } \\
\text { homogenous } \\
\text { hypoautofluorescent }\end{array}$ & $\begin{array}{l}\text { Either partial restoration } \\
\text { of outer retina or focal } \\
\text { areas of photoreceptors/ } \\
\text { RPE atrophy }\end{array}$ & $\begin{array}{l}\text { Normalisation } \\
\text { of choroidal } \\
\text { thickness }\end{array}$ & $\begin{array}{l}\text { Normalisation } \\
\text { of } \\
\text { choriocapillaris } \\
\text { flow }\end{array}$ \\
\hline
\end{tabular}


aetiology and associated systemic causes need to be ruled out. Laboratory investigations must include angiotensin converting enzyme (ACE) level and tuberculin intradermal reaction/Quantiferon test, considering the potential association of the disease with sarcoid or tuberculosis $[2,3,13,14,16]$. Considering the wide range of manifestations of ocular syphilis, exclusion of this condition should be part of the investigations.

In case of significant headaches and on suspicion of neurologic involvement, patients must be investigated with brain magnetic resonance imaging (MRI) and cerebrospinal fluid (CSF) examination. If cerebral vasculitis is suspected, MR angiography (MRA) is required [28].

\section{Management and prognosis}

In the acute stage of the disease, the use of antiinflammatory medications, including systemic steroids, is recommended to reduce the retinal damage. Generally, patients are started on a dose of $1 \mathrm{mg} / \mathrm{kg} /$ day of oral Prednisolone, which is gradually tapered over several weeks, pending on clinical response supported by imaging findings. In recurrent disease, the introduction of a second-line steroid-sparing agent, such as antimetabolite, usually mycophenolate mofetil, may be necessary. If an underlying infectious aetiology is identified, specific antimicrobic therapy is required, usually alongside antiinflammatory therapy. Patients with focal neurological symptoms require intravenous methylprednisolone, followed by a tapering course of oral steroids for at least 3 months. Patients with APMPPE and isolated headaches with a CSF pleocytosis should be treated with oral steroids.

Although the original description categorized APMPPE as a self-limited condition with a good prognosis, the reality is that the disease can be recurrent and result in significant visual loss, which can be the result of both direct central macular damage and the presence of large scotomas in a paracentral location. In a retrospective analysis and review of literature conducted by Fiore et al. in patients with APMPPE, at last follow-up visit visual acuity was $20 / 25$ or less in $42.3 \%$ eyes and $20 / 40$ or less in $23.7 \%$ eyes [57]. However, $71.9 \%$ eyes were symptomatic at last follow-up visit, underlining that patients with APMPPE might experience incomplete visual recovery [57].

\section{Method of literature search}

Literature search was undertaken in June 2021. A search of Medline, using PubMed and Google Scholar, was performed with no date restriction. The search used the following keywords: 'acute posterior multifocal placoid pigment epitheliopathy', 'APMPPE', 'placoid epiteliopathy', 'white dot syndromes'. Articles were selected based on clinical importance and categorized according to their relevance to the following section headings: epidemiology, demographics, etiopathogenesis, clinical features, imaging, management, and prognosis. Articles in languages other than English were considered if they provided an English abstract which could be used for screening their relevance.

\section{Acknowledgements}

None.

\section{Authors' contributions}

Ilaria Testi - Conceptualization, Writing - Original Draft. Sandra Vermeirsch Conceptualization, Writing - Original Draft. Carlos Pavesio -Conceptualization, Supervision, Writing - Review \& Editing. The author(s) read and approved the final manuscript.

\section{Funding}

This work was supported by the National Institute for Health Research (NIHR) Biomedical Research Centre based at Moorfields Eye Hospital NHS

Foundation Trust and UCL Institute of Ophthalmology. The views expressed are those of the authors and not necessarily those of the NHS, the NIHR or the Department of Health.

Availability of data and materials

Not applicable.

\section{Declarations}

Ethics approval and consent to participate

Not applicable.

Consent for publication

Not applicable.

\section{Competing interests}

The authors have no relevant affiliations or financial involvement with any organization or entity with a financial interest in or financial conflict with the subject matter or materials discussed in the manuscript. This includes employment, consultancies, honoraria, stock ownership or options, expert testimony, grants or patents received or pending, or royalties.

Received: 17 August 2021 Accepted: 30 August 2021

Published online: 16 September 2021

\section{References}

1. Gass JDM (1968) Acute posterior multifocal placoid pigment epitheliopathy. Arch Ophthalmol 80(2):177-185. https://doi.org/10.1001/archopht.1968. 00980050179005

2. Jones NP (1995) Acute posterior multifocal placoid pigment epitheliopathy. Br J Ophthalmol 79(4):384-389. https://doi.org/10.1136/bjo.79.4.384

3. Saleh M (2020 Feb) Placoid pigment epitheliopathy and serpiginous choroiditis. J Fr Ophtalmol 43(2):e55-e66. https://doi.org/10.1016/j.jfo.201 9.12 .001

4. Park D, Schatz H, McDonald HR, Johnson RN (1995) Acute multi-focal posterior placoid pigment epitheliopathy: a theory of pathogenesis. Retina. 15:351e352

5. Mrejen S, Sarraf D, Chexal S et al (2016) Choroidal involvement in acute posterior multifocal placoid pigment epitheliopathy. Ophthalmic Surg Lasers Imaging Retina 47:20e26

6. Yuzawa M, Kawamura A, Matsui M (1994) Indocyanine green video angiographic findings in acute posterior multifocal placoid pigment epitheliopathy. Acta Ophthalmol (Copenh) 72:128e133

7. Park D, Schatz H, McDonald HR, Johnson RN. Indocyanine green angiography of acute

8. Azar P, Gohd RS, Waltman D, Gitter KA (1975) Acute posterior multifocal placoid pigment epitheliopathy associated with an adenovirus type 5 infection. Am J Ophthalmol 80(6):1003-1005. https://doi.org/10.1016/00029394(75)90328-1 
9. Holt WS, Regan CD, Trempe C (1976) Acute posterior multifocal placoid pigment epitheliopathy. Am J Ophthalmol 81(4):403-412. https://doi.org/1 0.1016/0002-9394(76)90294-4

10. Comu S, Verstraeten T, Rinkoff JS, Busis NA (1996) Neurological manifestations of acute posterior multifocal placoid pigment epitheliopathy. Stroke. 27(5):996-1001. https://doi.org/10.1161/01.STR.27.5.996

11. Hernández-Da Mota SE (2016) Acute posterior multifocal placoid pigment epitheliopathy. Case report. Cir Cir 84(2):135-139. https://doi.org/10.1016/j. circir.2015.06.009

12. Bodine SR, Marino J, Camisa TJ, Salvate AJ (1992) Multifocal choroiditis with evidence of Lyme disease. Ann Ophthalmol 24(5):169-173

13. Anderson K, Patel KR, Webb L, Dutton GN (1996) Acute posterior multifocal placoid pigment epitheliopathy associated with pulmonary tuberculosis. $\mathrm{Br}$ J Ophthalmol 80(2):186. https://doi.org/10.1136/bjo.80.2.186

14. Abu-Yaghi NE, Hartono SP, Hodge DO, Pulido JS, Bakri SJ (Dec 2011) White dot syndromes: a 20-year study of incidence, clinical features, and outcomes. Ocul Immunol Inflamm 19(6):426-430. https://doi.org/10.3109/ 09273948.2011.624287

15. Dick DJ, Newman PK, Richardson J, Wilkinson R, Morley AR (1988) Acute posterior multifocal placoid pigment epitheliopathy and sarcoidosis. BrJ Ophthalmol 72(1):74-77. https://doi.org/10.1136/bjo.72.1.74

16. Darugar A, Mathian A, Lehoang P, Bodaghi B (2011) Acute posterior multifocal placoid pigment epitheliopathy as the initial manifestation of sarcoidosis. J Ophthalmic Vis Res 6(4):338-343

17. Wolf MD, Folk JC, Panknen CA, Goeken NE (May 1990) HLA-B7 and HLA-DR2 antigens and acute posterior multifocal placoid pigment epitheliopathy. Arch Ophthalmol 108(5):698-700. https://doi.org/10.1001/archopht.1990.01 070070084040

18. Kraemer LS, Montgomery JR, Baker KM, Colyer MH. Acute posterior multifocal placoid pigment epitheliopathy after immunization with multiple vaccines. Retin Cases Brief Rep. 2020

19. Brézin AP, Massin-Korobelnik P, Boudin M, Gaudric A, LeHoang P (1995) Acute posterior multifocal placoid pigment epitheliopathy after hepatitis B vaccine. Arch Ophthalmol 113(3):297-300. https://doi.org/10.1001/a rchopht.1995.01100030051021

20. Branisteanu D, Bilha A, Rom J (2015) Acute posterior multifocal placoid pigment epitheliopathy following influenza vaccination. Ophthalmol. 59(1): 52-58

21. Gonome T, Suzuki Y, Metoki T, Takahashi S, Nakazawa M (2016) Acute posterior multifocal placoid pigment epitheliopathy and granulomatous uveitis following influenza vaccination. Am J Ophthalmol Case Rep 4:60-63. https://doi.org/10.1016/j.ajoc.2016.08.008

22. Mendrinos E, Baglivo E (2010) Acute posterior multifocal placoid pigment epitheliopathy following influenza vaccination. Eye (Lond) 24(1):180-181. https://doi.org/10.1038/eye.2009.68

23. Fine HF, Kim E, Flynn TE, Gomes NL, Chang S (2010r) Acute posterior multifocal placoid pigment epitheliopathy following varicella vaccination. $\mathrm{Br}$ J Ophthalmol 94(3):282-283, 363. https://doi.org/10.1136/bjo.2008.144501

24. Raven ML, Ringeisen AL, Yonekawa Y, Stem MS, Faia L, Gottlieb JL (2017) Multi-modal imaging and anatomic classification of the white dot syndromes. Int J Retina Vitreous 3(1):12. https://doi.org/10.1186/s40942-0170069-8

25. Knickelbein JE, Sen HN (2016) Multimodal imaging of the white dot syndromes and related diseases. J Clin Exp Ophthalmol 7(3):570

26. Dunn JP (2016 Fall) Imaging in the white dot syndromes. Int Ophthalmol Clin 56(4):175-201. https://doi.org/10.1097//10.0000000000000145

27. Algahtani H, Alkhotani A, Shirah B (2016) Neurological manifestations of acute posterior multifocal Placoid pigment Epitheliopathy. J Clin Neurol 12(4):460-467. https://doi.org/10.3988/jcn.2016.12.4.460

28. Brownlee WJ, Anderson NE, Sims J, Pereira JA (2016) Neurological complications of acute multifocal placoid pigment epitheliopathy. J Clin Neurosci 31:76-80. https://doi.org/10.1016/j.jocn.2016.02.012

29. Collía Fernández A, García Sánchez JM (2020) Rivera-Pérez de Rada P, et al. recurrent Vertebrobasilar strokes associated with acute posterior multifocal Placoid pigment Epitheliopathy (APMPPE). Neurologist. 25(5):131-136. https://doi.org/10.1097/NRL.0000000000000273

30. Thomas BC, Jacobi C, Korporal M, Becker MD, Wildemann B, Mackensen F (2012) Ocular outcome and frequency of neurological manifestations in patients with acute posterior multifocal placoid pigment epitheliopathy (APMPPE). J Ophthalmic Inflamm Infect 2(3):125-131. https://doi.org/10.1 007/s12348-012-0077-7
31. Gupta V, Al-Dhibi HA, Arevalo JF (2014) Retinal imaging in uveitis. Saudi J Ophthalmol 28(2):95-103. https://doi.org/10.1016/j.sjopt.2014.02.008

32. Tugal-Tutkun I, Herbort CP Jr, Mantovani A, Neri P, Khairallah M (2021) Advances and potential new developments in imaging techniques for posterior uveitis. Part 1: noninvasive imaging methods. Eye (Lond). 35(1):3351. https://doi.org/10.1038/s41433-020-1063-1

33. Ciardella AP, Prall FR, Borodoker N, Cunningham ET Jr. Imaging techniques for posterior uveitis. Curr Opin Ophthalmol 2004;15(6):519-530. doi: https:// doi.org/10.1097/01.icu.0000144386.05116.c5. PMID: 15523198

34. Agarwal A, Invernizzi A, Markan A, Testi I, Keane PA, Agrawal R, Nguyen QD, Pavesio C, Gupta V (2020) Imaging in tubercular choroiditis: current concepts. Ocul Immunol Inflamm 28(8):1223-1238. https://doi.org/10.1080/ 09273948.2020.1817500

35. Agarwal A, Invernizzi A, Singh RB, Foulsham W, Aggarwal K, Handa S, Agrawal R, Pavesio C, Gupta V (2018) An update on inflammatory choroidal neovascularization: epidemiology, multimodal imaging, and management. J Ophthalmic In amm Infect 8(1):13. https://doi.org/10.1186/s12348-018-0155-6

36. Herbort CP Jr, Papasavvas I, Mantovani A (2020) Choriocapillaris involvement in acute syphilis posterior Placoid Chrioretinitis is responsible for functional impairment and points points towards an immunologic mechanism: a comprehensive clinicopathological approach. J Curr Ophthalmol 32(4):381389. https://doi.org/10.4103/JOCO.JOCO_184_20

37. Herbort CP Jr, Mantovani A, Tugal-Tutkun I, Papasavvas I (2021) Classification of non-infectious and/or immune mediated choroiditis: a brief overview of the essentials. Diagnostics (Basel) 11(6):939. https://doi.org/10.3390/dia gnostics 11060939

38. Park D, Schatz H, McDonald HR, Johnson RN (1995) Indocyanine green angiography of acute multifocal posterior placoid pigment epitheliopathy. Ophthalmology. 102:1877e1883

39. Heiferman MJ, Rahmani S, Jampol LM, Nesper PL, Skondra D, Kim LA, Fawzi AA (2017) Acute posterior multifocal placoid pigment epitheliopathy on optical coherence tomography angiography. Retina. 37(11):2084-2094. https://doi.org/10.1097//AE.0000000000001487

40. Oliveira MA, Simão J, Martins A, Farinha C (2020) Management of Acute Posterior Multifocal Placoid Pigment Epitheliopathy (APMPPE): insights from multimodal imaging with OCTA. Case Rep Ophthalmol Med. 2020:7049168

41. Browne A, Ansari W, Hu M et al (2020) Quantitative analysis of ellipsoid zone in acute posterior multifocal Placoid pigment Epitheliopathy. J Vitreo Retinal Dis 4(3):192-201. https://doi.org/10.1177/2474126420901897

42. Scheufele TA, Witkin AJ, Schocket LS et al (Dec 2005) Photoreceptor atrophy in acute posterior multifocal placoid pigment epitheliopathy demonstrated by optical coherence tomography. Retina. 25(8):1109-1112. https://doi.org/1 0.1097/00006982-200512000-00027

43. Goldenberg D, Habot-Wilner Z, Loewenstein A, Goldstein M (2012) Spectral domain optical coherence tomography classi cation of acute posterior multifocal placoid pigment epitheliopathy. Retina. 32(7):1403-1410. https:// doi.org/10.1097//AE.0b013e318234cafc

44. Lee GE, Lee BW, Rao NA, Fawzi AA (2011) Spectral domain optical coherence tomography and autofluorescence in a case of acute posterior multifocal placoid pigment epitheliopathy mimicking Vogt-Koyanagi-Harada disease: case report and review of literature. Ocul Immunol Inflamm 19(1): 42-47. https://doi.org/10.3109/09273948.2010.521610

45. Kitamura Y, Oshitari T, Kitahashi M, Baba T, Yamamoto S (2019) Acute posterior multifocal Placoid pigment Epitheliopathy sharing characteristic OCT findings of Vogt-Koyanagi-Harada disease. Case Rep Ophthalmol Med 2019:9217656

46. Kohli GM, Bhatia P, Shenoy P, Sen A, Gupta A (2020) Bacillary layer detachment in hyper-acute stage of acute posterior multifocal Placoid pigment Epitheliopathy: a case series. Ocul Immunol Inflamm 23:1-4

47. Mehta N, Chong J, Tsui E, Duncan JL, Curcio CA, Freund KB, Modi Y. Presumed foveal bacillary layer detachment in a patient with toxoplasmosis chorioretinitis and pachychoroid disease. Retin Cases Brief Rep. 2018

48. Cicinelli MV (2020) Giu ré C, Marchese a, et al. the bacillary detachment in posterior segment ocular diseases. Ophthalmol Retina. 4(4):454-456. https:// doi.org/10.1016/j.oret.2019.12.003

49. Fernández-Avellaneda P, Breazzano MP, Fragiotta S, Xu ZQ, Wang RK, Freund KB. Bacillary layer detachment overlying reduced choriocapillaris ow in acute idiopathic maculopathy. [published online ahead of print, 2019. Retin Cases Brief Rep. 2019

50. Agarwal A, Jindal AK, Anjani G, et al. Self-in icted laser-induced maculopathy masquerading as posterior uveitis in a patient with suspected IgG4-related 
disease. [published online ahead of print, 2019 Nov 8]. Retin Cases Brief Rep 2019

51. Furino C, Shalchi Z, Grassi MO et al (2019) OCT angiography in acute posterior multifocal Placoid pigment Epitheliopathy. Ophthalmic Surg Lasers Imaging Retina. 50(7):428436

52. Klufas MA, Phasukkijwatana N, lafe NA, Prasad PS, Agarwal A, Gupta V, Ansari W, Pichi F, Srivastava S, Freund KB, Sadda SVR, Sarraf D (2017) Optical coherence tomography angiography reveals Choriocapillaris flow reduction in Placoid Chorioretinitis. Ophthalmol Retina 1(1):77-91. https://doi.org/10.1 016/j.oret.2016.08.008

53. Burke TR, Chu CJ, Salvatore S, Bailey C, Dick AD, Lee RWJ, Ross AH, Carreño E, Medscape (2017) Application of OCT-angiography to characterise the evolution of chorioretinal lesions in acute posterior multifocal placoid pigment epitheliopathy. Eye (Lond). 31(10):1399-1408. https://doi.org/10.103 8/eye.2017.180

54. Durrani K, Foster CS (2012) Fundus autofluorescence imaging in posterior uveitis. Semin Ophthalmol 27(5-6):228-235. https://doi.org/10.3109/0882053 8.2012 .711414

55. Li AL, Palejwala NV, Shantha JG, O'Keefe G, Lee CS, Albini T, Yeh S (2020) Long-term multimodal imaging in acute posterior multifocal placoid pigment epitheliopathy and association with coxsackievirus exposure. PLoS One 15(8):e0238080. https://doi.org/10.1371/journal.pone.0238080

56. Souka AA, Hillenkamp J, Gora F, Gabel VP, Framme C (2006) Correlation between optical coherence tomography and autofluorescence in acute posterior multifocal placoid pigment epitheliopathy. Graefes Arch Clin Exp Ophthalmol 244(10):1219-1223. https://doi.org/10.1007/s00417-006-0343-1

57. Fiore T, laccheri B, Androudi S, Papadaki TG, Anzaar F, Brazitikos P, D'Amico DJ, Foster CS (2009) Acute posterior multifocal placoid pigment epitheliopathy: outcome and visual prognosis. Retina. 29(7):994-1001. https://doi.org/10.1097/IAE.0b013e3181a0bd15

\section{Publisher's Note}

Springer Nature remains neutral with regard to jurisdictional claims in published maps and institutional affiliations.

\section{Submit your manuscript to a SpringerOpen ${ }^{\circ}$ journal and benefit from:}

- Convenient online submission

- Rigorous peer review

- Open access: articles freely available online

- High visibility within the field

- Retaining the copyright to your article

Submit your next manuscript at $\boldsymbol{\nabla}$ springeropen.com 